\title{
Assessing the quality of the indoor environment of senior housing for a better mobility: a Swedish case study
}

\author{
Roya Bamzar $^{1}$ (i)
}

Received: 24 May 2017 / Accepted: 31 July 2018 / Published online: 9 August 2018

(c) The Author(s) 2018

\begin{abstract}
The aims of this article are to assess the quality of the indoor living environment of a senior housing (rental apartments for older adults aged 65+) in Hässelgården, Stockholm Municipality (Sweden's capital), in 2014, in relation to their mobility, and to suggest improvement strategies. First, the physical indoor environment of older adults is examined via a fieldwork checklist devised in accordance with the principles of universal design (UD). Second, their indoor environment is assessed through a survey that includes subjective questions about seniors' use of space, experience of falls, and safety perception. Third, the study explores whether the applications of UD in the seniors' indoor living environment contribute to the understanding of their use of space, experience of falls, and safety perception. Fieldwork inspections and a detailed survey with residents are used as a basis for the empirical analysis. Overall, 27 out of 56 questionnaires were collected, and ten apartments have been visited in the fieldwork. Findings indicate that the living room has the highest UD score compared with those for the kitchen and the bedroom. The older adults spend most of their time in the living room and the kitchen. A low UD score (e.g. kitchen and bedroom) is associated with a higher number of falls but not with low levels of safety perception and use of space. The article concludes with suggestions to improve housing safety of Hässelgården's senior housing, which may also help prevent falls in the older population elsewhere.
\end{abstract}

Keywords Housing adaptation · Older adults · Safety perception $\cdot$ Falls $\cdot$ Use of space

\section{Introduction}

As people age, their tendency to live in their own place increases (Andersson and Abramsson 2012; Sandstedt and Abramsson 2012). In other word, older adults prefer to remain in their homes and communities rather than institutional care as long as possible. This phenomenon is called 'ageing in place' (Davey et al. 2004). This is no surprise given that people's physical frailty increases with age; they are less mobile than those of young cohorts, spending most

Roya Bamzar

bamzar@kth.se

1 School of Architecture and the Built Environment (ABE), Royal Institute of Technology, Drottning Kristinasväg 30, SE 10044 Stockholm, Sweden 
of time indoors (Iwarsson et al. 2007). Results from a study conducted by Abramsson and Andersson (2016) on changing preference of housing choice with ageing in Sweden indicate that Swedes tend to change their housing from large to small, and from owner occupation to rental housing as they age. Furthermore, there is a tendency among Swedish older adults to move in more comfortable housings that need less maintenance (Abramsson and Niedomysl 2008; Abramsson et al. 2014).

This situation makes the 'older adults' house an important setting to be studied in relation to how residents perceive and use this environment. Falls are the leading cause of injuries and death among the older population worldwide [World Health Organization (WHO) 2016], and Sweden is no exception. Nilson (2014) found that most of all fatal injuries among older Swedes are because of falls. The results of two recent studies in Sweden indicate that $57 \%$ of all falls in the older population are caused by slipping, tripping, and stubbing; these falls often take place indoors, and in the seniors' immediate environment, with the long winters helping to explain the seniors' increased tendency to stay indoors (Bamzar and Ceccato 2015, 2016; Ceccato 2016). This study builds on the work done by Bamzar and Ceccato $(2015,2016)$ and Ceccato (2016). Through the use of a case study, this study aims to assess the safety quality of the indoor living environment of senior housing, namely Hässelgården's senior housing. This study sets out to examine how the physical features of the indoor environment of older adults' houses may influence and be related to their use of space, experience of falls, and safety perception.

Hässelgården is situated in Stockholm, the capital of Sweden, which is located in the centre-south of the country. The study begins with an examination of the physical indoor environment of the older adults living in Hässelgården's senior housing via a fieldwork checklist ("Appendix 1") designed in accordance with the principles of universal design (UD). Next, the indoor environment of this older population is assessed through a survey ("Appendix 2") that includes questions about the seniors' use of space, experience of falls, and safety perception.

It is expected that the parts of an apartment with higher UD score were those used more frequently by residents. Lower UD scores of some parts indicate the higher number of falls there. And finally, higher levels of adaptation of UD principles in some parts of the apartments would contribute to higher safety perceptions by the participants. Based on the findings of the study, the article concludes with suggestions to improve the housing safety of Hässelgården's senior housing, which may also guide safety promotion in the older population elsewhere.

\section{Literature review}

Overall, the daily life and routine of older adults is affected and may be changed by physical and social features of the built environment. To understand this better, it is needed to define older age, what we mean by environment, and to describe aspects of older adult's life that may be influenced by the environment.

\subsection{Older adults' houses}

\subsubsection{Older age}

Conventionally, a chronological age of 65 years or older is defined as older age. Scholars suggest that ageing is usually associated with dependency, loss of functionality, and cognitive impairment (Orimo et al. 2006). Studies show that in addition to physical functionality 
decline, cognition also may change with ageing. Some brain mechanism such as perception, speed thinking, the function of the memory, and new information retrieval may tend to decline as people age (Borson 2010). Because the healthy life expectancy of seniors has increased, seniors have become more active and independent compared with those living decades ago. However, seniors living in different countries (developed and developing countries) experience different lifespans based on their health and socio-economic status (Agahi and Parker 2005). Therefore, it may be concluded that, realistically, the definition of age must be adjusted according to the circumstances of a geographical region, and socioeconomic statue in which the population lives.

\subsubsection{The meaning and use of 'home' by older adults}

A home is a house that can fulfil the needs of its residents (Demirbilek and Demirkan 2004); on the other hand, the older adult's tendency is to remain at their home and community as long as possible independently (ageing in place). This is not possible unless the living environment provides enough opportunities to fulfil the residents' daily needs. The frailty, cognitive impairment, and weaker motor coordination associated with ageing impede older individuals from performing their daily routine safely (Fielo and Warren 2001). In addition, long-standing illnesses in this age group restrict the older adults from going out more often (Ayis et al. 2003). Regarding these, a home cannot be defined simply as a physical space (Wahl and Oswald 2010). A Swedish study suggests home means security and safety as well as freedom for older adults (Dahlin-Ivanoff et al. 2007). The aspects related to the safety and security are living in familiar area, having memories to continue the life, and living in a place with proper functionality. Freedom is related to a place for reflection, and social life. In their 2004 study, Forlizzi, DiSalvo, and Gemperle focused on how the environment is perceived by older adults in relation to their domestic lives. They highlighted the importance of the design of physical features of the living environment and of assistive products in either maintaining or decreasing the independence of the older persons. Their findings showed that many aspects of a typical senior's apartment fail to fulfil the residents' needs properly. For example, the bathrooms and kitchens had some inadequacies that can limit the daily activities of the older persons. These inadequacies included the storage of unnecessary appliances and food on kitchen countertops and the positioning of cabinets and shelves out of reach for residents. Moreover, the tendency of people to maintain their belongings at their homes increases in the later life. According to Ekerdt et al. (2004), there are reasons for this tendency: (1) these belongings may be useful 1 day. (2) The belongings are worth money. (3) People perceive some belonging as beautiful that can give them pleasure. (4) Some belonging may express our identity.

\subsubsection{The risk of injuries in older adults' houses}

Scholars suggest that certain aspects of the environment and the settings to which older people are daily exposed increase their risk of falls (Letts et al. 2010; Stevens et al. 2001). The results of a retrospective study in Australia indicate that older persons who live in houses with more environmental hazards (e.g. inadequate lighting, slippery and uneven floor surfaces, absence of appropriate grab bars/handrails on stairs) have a 2.8 times greater risk of experiencing at least one injury (Carter et al. 2000). The relationship between the presence of environmental hazards and the prevalence of falls has also been highlighted in other studies (Northridge et al. 1995; Berg et al. 1997; Connell et al. 1997; Fuller 2000; 
Gill et al. 1999). Northridge et al. (1995) described that in the USA, certain home hazards such as clutter and hall rug problems are crucial factors in predicting falls among healthy, active older adults. Carrying heavy or bulky objects, walking on slippery floors, and living with poor lighting may increase the risk of falls (Stevens et al. 2001). Carter et al. (2000) illustrated that the kitchen is the place where most non-fall injuries (31\%), including burns, knocks, cuts, and bumps, take place, whereas fall-related injuries happen most frequently $(20 \%)$ in the bedroom. Bedrooms were recognized as places with the highest rate of older adults' indoor falls in other studies as well (Reinsch et al. 1993; Connell et al. 1997). The presence of unstable furniture pieces (e.g. unanchored tall shelves), electrical cords, and inappropriately assembled bed frames, as well as poor lighting at night, may also increase the risk of falls in the bedroom. The implementation of environmental modifications to a living space so that occupants can live safely, despite their physical limitations, has been identified as an appropriate policy to decrease the risk of falls (Fänge and Iwarsson 2005; van Hoof et al. 2010).

\subsubsection{The perceived safety in older adults' houses}

Studies have revealed that the design and physical features of the living environment as well as the arrangement of furniture influence the safety perception of the older adults (Alcántara et al. 2005; Ishihara et al. 1997). Moreover, Zamora et al. (2008) suggested that despite a higher number of fall incidents in some areas of an apartment, older people feel safer owing to the presence of some physical features that are specially designed for the older persons. Moreover, textures (e.g. shiny floors), dark colours, and surrounding ambience have an important influence on seniors' perception of the environment as unsafe. However, the mechanisms linking perception and the characteristics of the domestic environment are not clear. What is known is that minor details of an apartment's design and physical environment can influence the perception of freedom of movement and the risk of falls and other accidents at any age (Yiannakoulias et al. 2003). The results of a Brazilian study indicate that environments that provide higher levels of physical activities are perceived to be safer by older persons (Weber Corseuil et al. 2012). Leonardi et al. (2009) suggested that the distribution of several types of objects in different areas of the home determine which areas are more frequently used. Moreover, the type of activities related to each area of the home is another determinant factor. According to the results of that study, the living room and the kitchen are the most commonly used areas and that the bedroom is a less frequently used area of a house.

\subsection{UD principles and older adults' houses}

A home and its surrounding environment should be designed in a way that can be adapted to a wide range of people with different needs. The concept of UD, often referred to as 'inclusive design' in Europe (Persson et al. 2015), helps to provide an environment that is fit for all. According to Mace et al. (1991:156), UD is 'an approach to creating environments and products that are usable by all people to the greatest extent possible' and is composed of seven principles, namely: equitable use, flexibility in use, intuitive use, perceptible information, tolerance for error, low physical effort, and size and space for approach and use. The aim of UD specified for the ageing population is to provide a safe environment so as to enable older people to perform and conduct their daily activities independently (Crews and Zavotka 2006). It stems from barrier-free and accessible design 
approaches. However, a barrier-free environment for one person can be a barrier for someone else (Mace et al. 1996). Therefore, the solution involves not only removing the barrier but also giving the designer the opportunity to address the issue from a broader perspective (Persson et al. 2015). Accessibility is related to a design process, and it focuses on how the design is simplified with regard to distance and time to allow individuals to perform activities in society (Pirie 1979). Within the concept of accessibility, the interaction between the environment and the person's functional capacity is often disregarded (Preiser and Ostroff 2001). Although applying features of barrier-free and accessible design approaches to the physical environment could help to provide better accessibility and usability, these features are visible enough to create a sense of segregation in the environment among users (Deardorff and Birdsong 2003). Though this sense of segregation is more meaningful in public spaces, private areas (homes) also matter. As each feature for accessible design in home may remind the user his/her disability.

Accessible design specifically focuses to provide design features for those people with limited performance in any activity, while UD is more related to people of all ages and abilities. In the concept of accessibility, the regulations and criteria are set to provide a minimum level of requirements to accommodate people with disability. So, although accessible design emerges from the idea of interplay between individual's ability and the capacity of the environment, it minimizes the ability of individual to accommodate their needs (Preiser and Ostroff 2001).

UD is more about democracy (compared to other design framework), design for all, and social inclusion (Iwarsson and Ståhl 2003). UD is a framework to practise design, and it means that people with limited mobility or a disability should not be excluded and segregated by design. According to this philosophy, the solution suggested by the designer of a building to help provide better accessibility for those with disabilities should also work for everybody. In other words, the design of a building should be based on the needs of every stage of human life.

There are several guidelines for designing a home for the older adults based on the principles of UD. In general, accessibility is the most essential element that needs to be taken into account when designing for the older persons. Fewer doors, hallways, and rooms make a home more accessible for people with limited mobility (Baldrica 2003). For instance, the kitchen is usually designed in such a way that the stove, refrigerator, and sink are three vertices of a triangle. The bathroom should be also located within the shortest distance possible to the bedroom and should have certain features such as grab bars near the toilet, a non-slip mat on the shower floor, various lighting options such as a dimmer (to adjust the rate of illumination), for those with limited mobility (Baldrica 2003).

Like other design standards, UD also has a number of limitations. Iwarsson and Ståhl (2003) suggested that applying the principles of UD into practice is still an awkward process because there is a lack of adequate education among the involved stakeholders (e.g. planners, engineers, and architects). Furthermore, there is a discrepancy in reporting the cost of implementation of the principles of UD between researchers and professionals. The construction costs of a building will increase if at least some of the principles of UD are applied, for example, a larger bathroom and its accessories (Commission for Architecture and the Built Environment 2008). Moreover, in lower-income areas, if any adaptation takes place based on UD principles in existing housing, it would increase the rental cost of the housing for tenants. In the particular case of older adults with limited financial means, this would be more problematic to pay higher cost in exchange for housing modifications.

Finally, a lack of communication and participation involving the end users of UD in the related guidelines and codes is another challenge associated with UD (Carr et al. 2013). 
Newell and Gregor (2000) also argued that designing a product that is usable for a group of people with a certain type of disability can make the use of the product more difficult for people with no disability or with other different types of disability. Yet, in Sweden, the goal is achieving an accessible society rather than simply applying the principles of UD (Montefusco 2016).

\section{The conceptual framework}

The aims of this study are to assess the safety quality of the indoor living environment of senior housing (rental apartments for older adults age 65+) in Hässelgården, Stockholm Municipality (Sweden's capital), in 2014, and to suggest improvement strategies. The physical layout and design features of older adults' homes influence the way in which they use and perceive them (Zamora et al. 2008; Yiannakoulias et al. 2003; Leonardi et al. 2009). In addition, physical attributes of older adults' houses (e.g. slippery floors, insufficient illumination) have long been associated with injuries among the older adults (Letts et al. 2010; Stevens et al. 2001); therefore, it could be expected that some environments are riskier than others for older adults.

The principles of UD are expected to work as a reference for promoting environments that are adapted for all, including the needs of older adults. In this study, UD principles are used as a reference for comparison with what is found in Hässelgården's senior housing in Stockholm, Sweden. Therefore, it could be expected that the more these environments share UD qualities, the more adapted they are to meet the needs of older adults. Based on these assumptions, Hässelgården's senior housing is expected to have the following features:

1. The areas of an apartment with higher UD scores (e.g. the living room) are used more frequently by residents (Zamora et al. 2008; Yiannakoulias et al. 2003; Leonardi et al. 2009).

2. A higher number of falls take place in the areas of an apartment with lower levels of adoption of the principles of UD (e.g. the kitchen; Letts et al. 2010; Stevens et al. 2001).

3. The areas of an apartment that are perceived safer by residents are those with better levels of adoption of the principles of UD (e.g. the living room). Residents have a greater tendency to spend more time and feel safe in those areas of an apartment (Zamora et al. 2008; Yiannakoulias et al. 2003; Leonardi et al. 2009).

\section{The case study: Hässelgården senior housing}

This case study focuses on Hässelgården's senior housing, which is located in Hässelby district, on the outskirts of Stockholm Municipality. The senior housing is rental apartments, adapted for good accessibility for people aged 65 or over. People who are 65 years and older and registered in the City of Stockholm have permission to apply for these apartments directly from Stockholm Housing Service (Bostadsförmedlingen), and they must pay the full rent. The owner of the housing is Micasa Fastigheter (a subsidiary of Stockholm municipality). Hässelgården senior housing has one of the lowest rental costs among Micasa's senior housing because they offer few adaptations for their older persons occupants. 
The home care services are provided whether by municipality or private companies based on the resident's chose.

Hässelgården's senior housing comprises 83 two-room apartments $\left(52-57 \mathrm{~m}^{2}\right.$ each, 560-614 square feet), which were built in 1973, and are located a long distance from Stockholm's city centre, (15 km, $9.5 \mathrm{mi}$, about $40 \mathrm{~min}$ by train). The average annual income is SEK 294 000, which is slightly lower compared with Stockholm as a whole, where the average annual mean income is SEK 342300 (1 SEK=0.11 EUR) (SCB 2015). Hässelgården senior housing was selected as a case study because it could typify present situation of older persons living areas in Stockholm in terms of physical environment. Moreover, the apartments with the least adoption may expose older adults to hazards and consequently influence the likelihood of fall, use of space, and safety perception.

\section{Data and methods}

All the data used in this study are primary data and were collected by conducting a survey and performing fieldwork in Hässelgården's senior housing. The data were processed with descriptive statistics (spread sheet) a tool for visualizing data (graph and chart) in collected empirical material so as to have a better handle on the data (Befring 1994).

\subsection{Data collection: checklist design}

A checklist was designed by Bamzar (2014) in accordance with the seven principles of UD and based on studying housing checklist manuals related to UD principles as well as fall prevention measures (Sandler 2016; Centre for Disease Control and Prevention 2005; Home Modification 2008). The reason to create a new checklist is to combine two groups of home checklist as basis: the group one particularly targets those features that may increase the risk of fall, and the other group of questions targets those features related to UD principles. Moreover, the new checklist was modified according to the layout and physical features available in Hässelgården senior housing. Two visits from Hässelgården senior housing apartments were carried out before finalizing checklist design to make sure every physical feature of the apartments is included in the checklist.

The checklist includes 61 questions about physical features for accessibility and usability and potential risk factors for falls that are present in different areas of an apartment such as the kitchen, bedroom, living room, and bathroom. However, these questions are not only related to the layout, and design of the apartments, but also, they touch upon the residents' placement of furniture and arrangement. Each question on the checklist is an indicator for UD principles. Ten apartments were visited by Bamzar in 2014; however, each apartment may have been visited two to three times, and each visit took $1 \mathrm{~h}$ to be performed. The physical features of each area of the apartments are analysed and scored based on fieldwork (checklist) results.

\subsection{Checklist analysis}

Analysing these data involved relating each question on the checklist with one to three principles of UD. If the presence of that condition asked in the question is confirmed, each related principle to that question is graded one; otherwise, it is graded zero. Finally, the sum of all obtained grades for each principle is divided by the total number of questions 
related to that principle in each area of the apartments. For instance, if the question is about the presence of walking space around the bed, this is related to the seventh principle: size and space for approach and use. If the answer is yes, the number one is assigned to this question. The same rule is applied for other questions related to size and space in the bedroom. Let's consider there are five questions about size and space on the bedroom checklist, of which the answer for two of the questions is yes. Then, the bedroom score regarding size and space is 40 of 100 . The score for the 10 visited bedrooms with regard to size and space for approach and use is the average of the scores for each apartment bedroom in terms of size and space for approach and use. This grading system suggests a score equivalent to each principle of UD for each part of the apartment.

\subsection{Data collection: survey design}

A survey consisting of 43 questions was conducted in fifty-six of the two-room apartments. The choice of a two-room apartment is explained by the fact that in a one-room apartment, the residents do not have many choices in the use of their space, but there is a clearer picture of the older population's use of space, routine path, and daily activity environment in a two-room apartment. The survey questions were mostly structured with a few open-ended questions. In the survey, open-ended questions are asked to explain whether the respondents have any experience of fall and any complains of use of space. The questions on the survey focused on older adults' use of space, safety perception, and experience of falls in different areas of an apartment. In the survey, safety covers both the risk of an individual to falls (with health-related implications) and the risk of being a victim of crime. Safe environments in this study are those that allow free movement and have no risks for falls or other types of threat to life and health. Then, all the residents participating in the study were invited to a preliminary meeting for more clarification about the survey questions, the aim of the study, and the any possible questions. A pilot-tested was carried out prior to this meeting with six participants (from Hässelgården) to improve the survey design and questions. Table 1 shows the demographic characteristics of the participants of the survey.

\subsection{Survey analysis}

Overall, 56 questionnaires were distributed, of which 27 were collected. In other words, the response rate of the survey was $50 \%$ of which $37 \%$ were face-to-face interviews, and $63 \%$ were questionnaires. Each area of an apartment is identified by the number of respondents declaring that area as the safest/least safe, the most/least used, and the riskiest place for falls. A graph is used to represent the results of the analysis of these data. The primary intention was to have a face-to-face interview with all participants. However, a few numbers of participants (eight persons aged 65-75 years) accepted to be interviewed. The interviews were note-taking, and it took $2 \mathrm{~h}$ including pause to perform the interview in average. Six of the interviewees were women and two were man. I also made use of narrative approach to capture the emotion and perception of story tellers at the time of her/ his experience. Narrative approach is a collection of stories from individuals about individuals' experience that is documented by the interviewer (Creswell 2013). All the narrations available in this study were collected through the interviews. The selected stories are those that physical features and layout of the apartments play a significant role in shaping the story. Moreover, some of the participant had some experiences in common with other participants. 
Table 1 The characteristics of the older persons sample in Hässelgården senior housing. Source: Fieldwork in Hässelgården 2014

\begin{tabular}{lc}
\hline Characteristics & $N=27$ \\
\hline Gender & \\
Female & 17 \\
Male & 10 \\
Age & \\
$65-69$ & 6 \\
$70-74$ & 7 \\
$75-79$ & 4 \\
$80-84$ & 5 \\
$85+$ & 5 \\
Marital status & \\
Married & 4 \\
Widowed & 20 \\
Divorced & 1 \\
Others & 2 \\
Ethnicity & \\
Native Swedish & 22 \\
Foreign born & 5 \\
Time of residence & \\
Less than 1 year & 8 \\
Between 1 and 5 years & 14 \\
More than 5 years & 5 \\
\hline
\end{tabular}

The presence of any relationship between the UD score of each area of the apartments and the related percentage of frequency of use, number of falls, and perceived safety is investigated separately. The study utilized a multimethod approach to capture the associations between UD score of the older adult's apartments and experience of fall, safety perception, and use of space. The aim of using multimethod approach in research design is to combine various research methods, as a single method may not be sufficient to obtain a deeper understanding of the experiences and attitudes of the participants (Teddlie and Tashakkori 2009; Bricki and Green 2007).

\section{Results}

In this section, first the scores of the different parts of older adult's apartment in Hässelgården senior housing (based on the checklist analysis) are reported, and second, the results of the survey are described. The survey analysis highlights how older adults in Hässelgården perceive safety, experience fall-related injuries, and use their indoor environment.

\subsection{UD principles and older adults' apartments in Hässelgården}

In this section, we report the scores of the UD principles attributed to different indoor environments of older adults' apartments in Hässelgården. Figure 1a presents the layout of an apartment. Figure $1 \mathrm{~b}$ shows the UD scores for all areas of the inspected apartments. The 
findings show that the living room has the highest score for UD principles, followed by the bathroom and the kitchen, whereas the bedroom has lowest. The living room is the space between the kitchen and the bedroom and has an entry to the balcony.

The living room is large enough to accommodate several types of furniture, such as sofas and tables, which are often used by older adults for support when walking or standing up. Moreover, light switches and electrical outlets were well placed within easy reach for older users. These living-room features contribute to flexibility in use and simple and intuitive use. However, many of the inspected living rooms had loose electrical cords on the floors (instead of being placed along walls and away from high traffic areas), which constituted a clear hazard and a risk for tripping and falling. The presence of extra furniture in the living room also represented a hazard for it affects the ability of older adults to move easily. There were also cases in which residents used more than one or two carpets to cover the floor, the presence of which potentially contributes to fall-related injuries.

Each bathroom was installed with a single lever mixing faucet. This type of faucet handle is easy to grasp, making it simple and intuitive to use. Although grab bars were

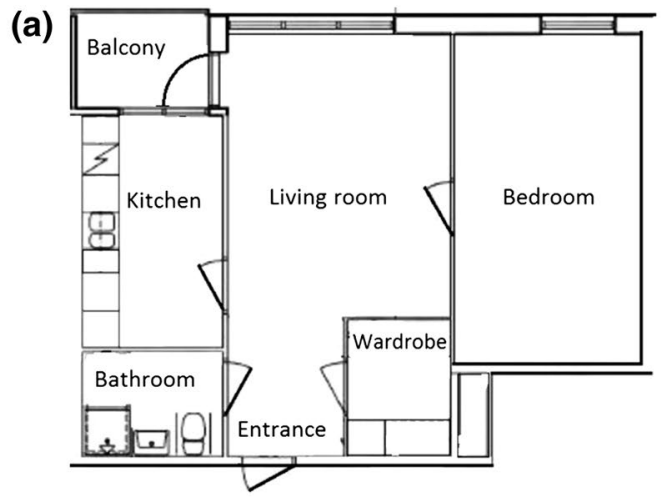

(b)

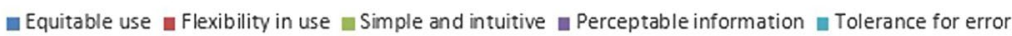
घ Low physical effort $\square$ Size and space for approach and use

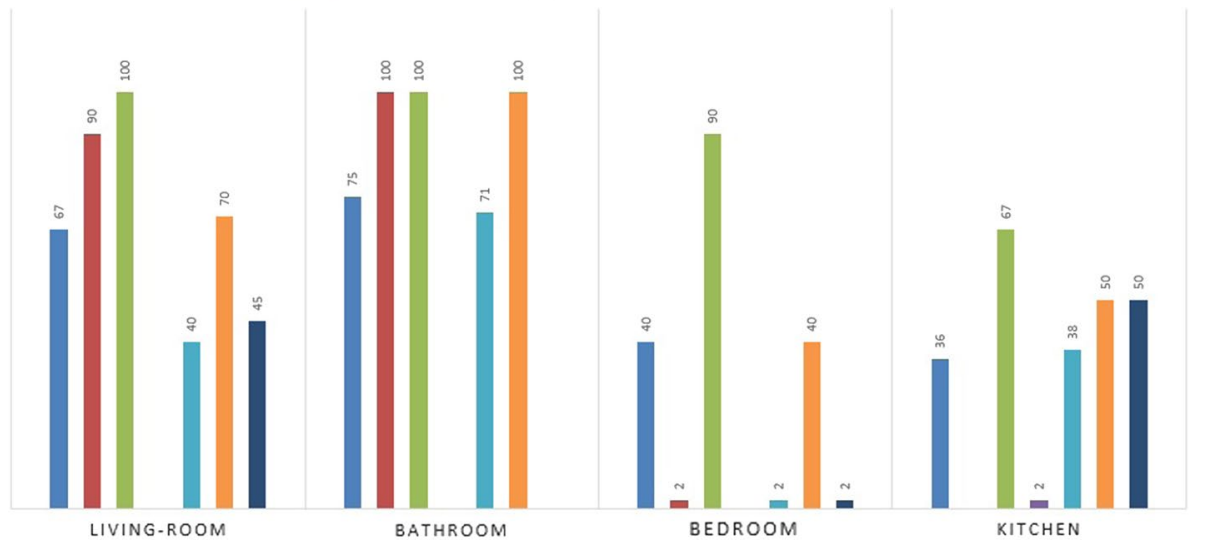

Fig. 1 a The layout of an apartment (52-57 m²) in Hässelgården's senior housing. Source: Fieldwork, 2014. b Scores attributed to different areas of the inspected apartments based on UD principles. Source: Fieldwork inspection of a sample of apartments, 2014; $N=10$ 
installed on the wall by the shower area and the toilet in most cases, there were no non-skid mats or strips on the shower floor in any of the visited bathrooms.

The toilet and sink are made of porcelain, but these surfaces are not soft enough from a safety perspective. The presence of this type of feature may increase the severity of falls and indicate a lower level of tolerance in error in bathrooms. According to the UD score, the bedroom is the worst area of an apartment. The lack of walking space around the bed, the lack of light to brighten the way to the bathroom at night, and the lack of wall-to-wall carpeting contribute to lower levels of flexibility in use and tolerance in error. However, most bedrooms are equipped with a lamp or a flashlight kept within reach of the bed and a sturdy chair with arms where one can sit to dress; these features promote equitability in use and low physical effort.

Some deficiencies were also detected in other areas such as the kitchen and the balcony. For instance, the stoves did not have exhaust hoods; nor did they have alarm or automatic shut-off systems. In addition, many kitchen countertops and work areas were cluttered with unnecessary objects (those objects such as knives, spoons, dishes, or other stuff of the kitchen that should be placed in the cabinets after using). Some balconies were adorned with unsteady objects and had thresholds that had not been bevelled. These balcony features may trigger falls for residents. However, the balcony is the area of an apartment that is generally used only in summertime.

\subsection{The daily use of older adults' apartments}

Figure 2 shows the different areas of senior housing apartments and the percentages of participants who fall, feel safe, and spend more of their time in each of these.

The results of the survey revealed that the living room was the most frequently used area of an apartment, with residents spending almost twice as much time in the living room than in the second most frequently used area, the kitchen.

However, residents suggested that if the kitchen were large enough, they would prefer to spend their time in the kitchen rather than any other area in their apartments. One resident noted:

'The kitchen is too small to be there. If it had been big enough to put a comfortable sofa/chair or my laptop there, I would not have to go to the kitchen for coffee or food' (a 72-year-old lady)'.

Moreover, other respondents argued that they would spend more time in the kitchen if there were a proper ventilation system. One participant described the situation as follows:

'When I am cooking, I have to open the window, even in winter. The exhaust hood in my kitchen does not work properly. I often forget that I've put something in the oven.

Being in the kitchen helped me not to forget about it (A 71 year-old man).

Figure 3 presents two photographs of a typical kitchen in Hässelgården's senior housing.

Not surprisingly, the participants' use of the balcony depends on the season and the number of sunny days. Many of the participants spend some of their time on the balcony instead of the living room during the summer. The bedroom is not used very much during the day, with the participants generally waiting until bedtime to go there. There were complains about ventilation system. They would like a proper ventilation system to be installed so as to improve the air quality in the bedroom. In addition, the lack of walking space 


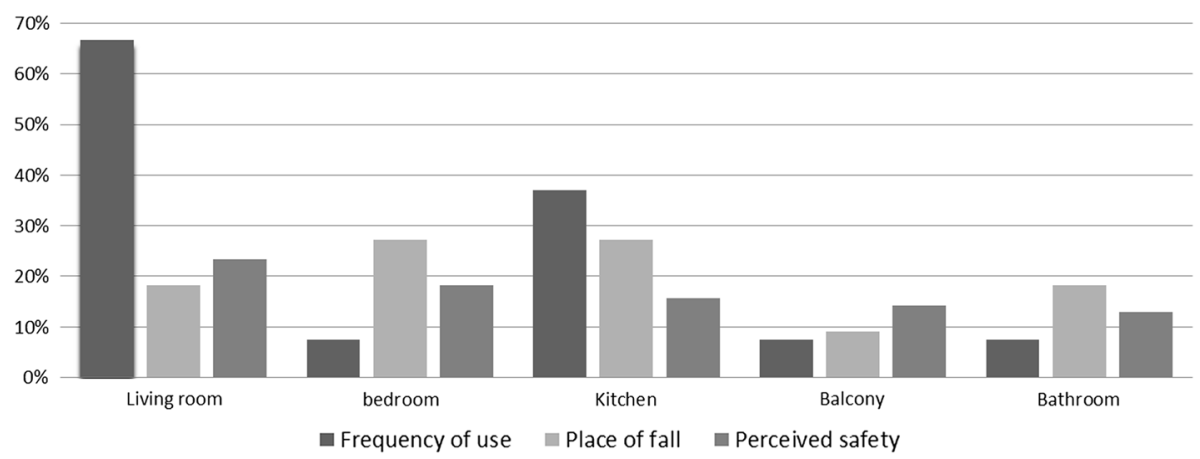

Fig. 2 Frequency of use, place of fall, and perceived safety (\%) in different areas of senior housing apartments ( $N=27$ older adults respondents). Source: Fieldwork in Hässelgården, 2014

around the bed impeded participant's ability to move properly in the bedroom. One mentioned that

'My bedroom is cramped, and the walking space around my bed is very limited. I experience difficulties when making my bed or adjusting the sheet and pillow' (a 75-year-old man).

\subsection{Older adults' apartments and the areas where falls occur}

One-fourth of the respondents experienced falls in their apartments, of which half of them experienced multiple falls. Overall, seven people have experienced fall in their apartments from 2013 December till July 2014, of which three people have experienced multiple fall in the different parts of the apartment. Thus, eleven falls have been taken place. However, except one, the rest of falls were not serious. Figure 4a shows the environmental features that may trigger falls and injuries, and Fig. 4b shows a number of apartment features that promote safety in Hässelgården's senior housing.
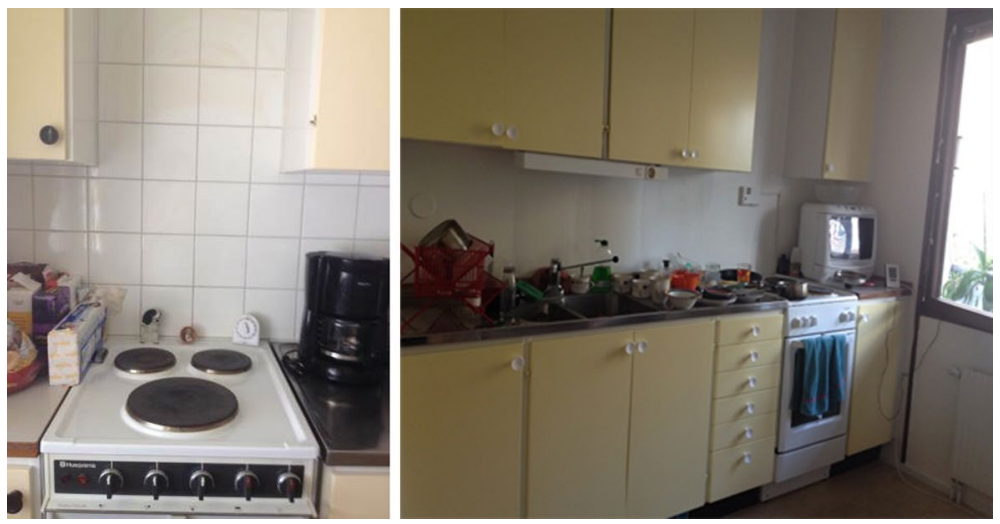

Fig. 3 Hässelgården's senior housing — a typical kitchen. Photographs: Bamzar (2014) 
The kitchen and the bedroom are the most common areas for falls (three incidents of fall have taken place in each), followed by the bathroom (two events of fall) and the living room (two events of fall plus one event in balcony). One participant described her multiple falls in the bathroom as follows:

'I fell when I was taking a shower in the bathroom. I slipped on a rug and fell down. Stone floors there. I woke up on the floor the next morning, and, fortunately, everything went fine. Another time in the early morning in my previous apartment, I fell from the toilet chair. I had taken very strong medicine. My head was close to being injured from [hitting] the hard toilet (a 70-year-old man)'.

Another fall incident occurred in the bedroom:

'At midnight, I woke up to go to the toilet. I didn't turn on the light. There was something in my way, and I fell badly. I was found by my grandchild the next morning. My head had been injured (a 73-year-old lady)'.

Although the number of falls is not high in bathrooms, there are triggers that might be risky for fall for the older adults. For instance, the toilet is made of porcelain, a hard material that when struck can turn a seemingly simple fall into a serious head injury.

\subsection{Older adults' apartments and residents' perceived safety}

The survey respondents regarded the living room as the safest area of their apartments, followed by the bedroom and then the kitchen. Although around $40 \%$ of the participants thought that all areas of their apartments are safe, there were cases who indicated that they felt partially safe or even totally unsafe in all areas of their apartments. Moreover, one-ninth of the participants felt totally unsafe even in the living room. One participant described this feeling as follows:

'Nowhere I feel safe here; I am not able to use my walking aid inside my apartment as it [the apartment] is too small. I have a visual impairment. I am always fearful of walking since there is no handrail or support for me to [help me] walk. I always feel unsafe' (a 73-year-old lady).

The older persons residents declared the bathroom to be the least safe area of their apartments areas.

\section{Discussion of the results}

In this section, the findings of the survey and checklist analysis are compared to find out whether UD scores of each part of the apartments can describe lower/higher number of falls, frequency of use of space, and safety perception of the participants. Compared with the kitchen and the bedroom, the living room received the highest UD score.

The survey findings also show that it is in the living room where seniors spend most of their time. Some studies (e.g. Leonardi et al. 2009) have emphasized the importance of the distribution of objects in different areas of an apartment so as to achieve higher usability. However, our results show that this is not the case. In other word, although kitchen usually is the place where people of this age spend time (because of the distribution of objects), the lack of proper physical adaptations to meet the needs of seniors in the kitchen prevents 
(a)
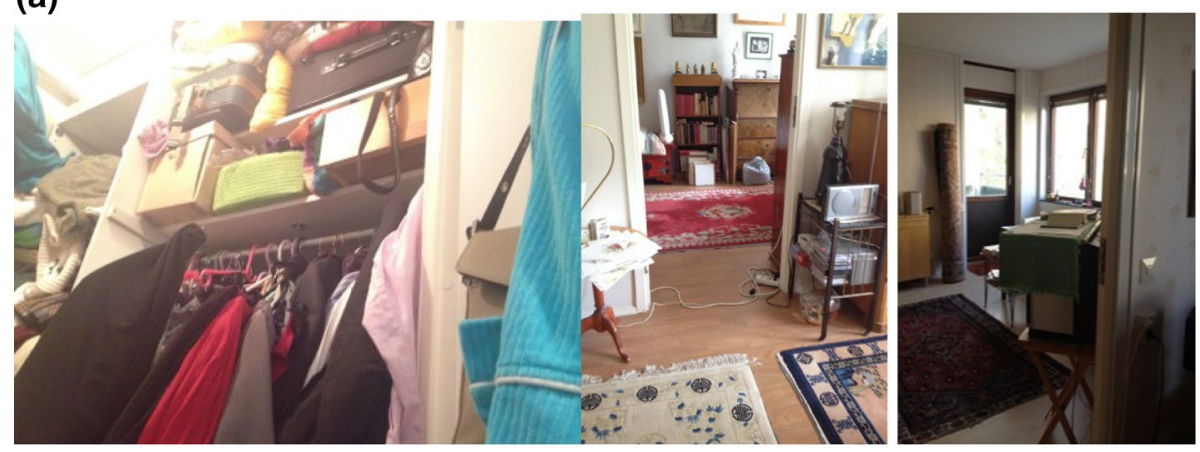

(b)
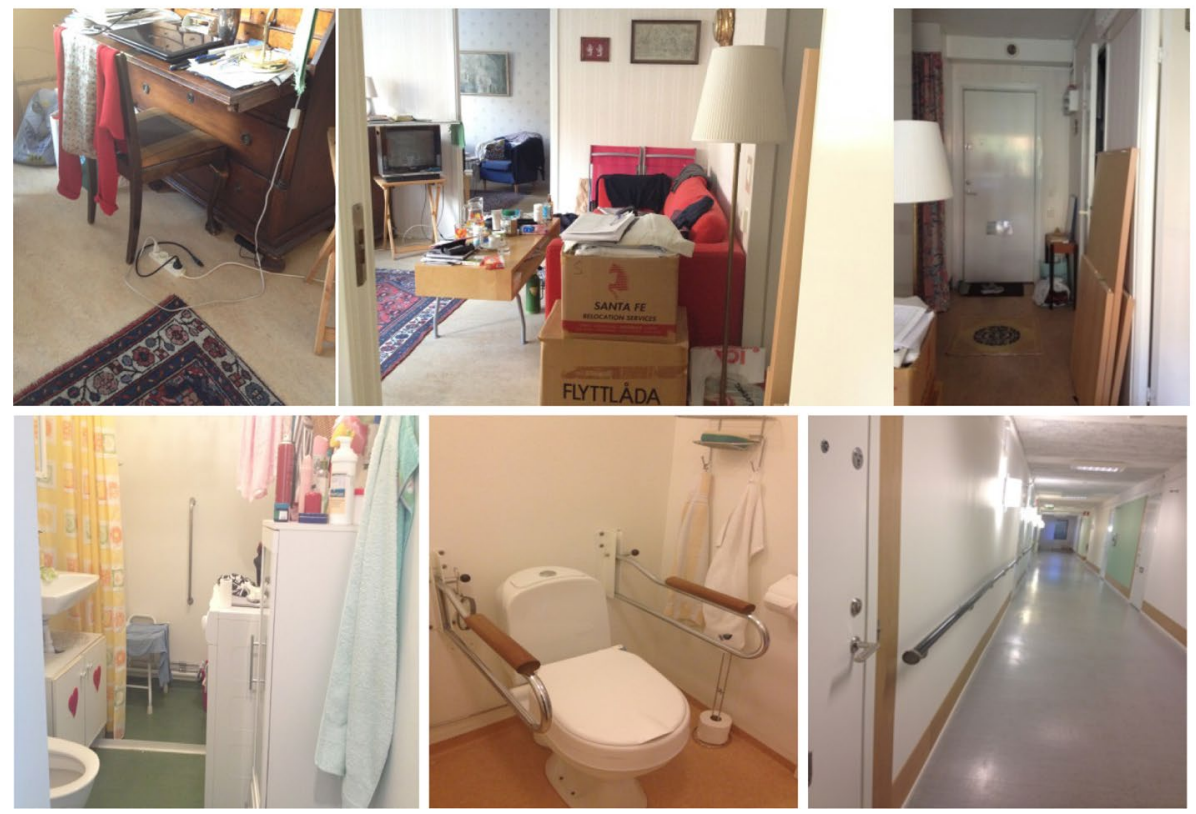

Fig. 4 a Hässelgården's senior housing —environmental features such as electrical cords, boxes and tables that promote accidents. Photographs: Bamzar (2014). b Features promoting safety: presence of handrails and grab bars in the bathroom and toilets and sufficient illumination in the corridor. Hässelgården's senior housing. Photographs: Bamzar (2014)

them from doing so in this case study. In Hässelgården's senior housing, the living room is adjacent to the kitchen. Therefore, the amount of walking required to perform daily routine activities between these two areas is also minimized (enhanced accessibility), which is a great benefit for someone with limited mobility and stamina.

As expected, low scores with regard to UD principles (particularly tolerance of error) contribute to higher numbers of falls (e.g. kitchen and bedroom). This result is confirmed by several studies. The presence of hazards in the environmental setting (that has not been designed according to UD principles) increases the risk of falls for the older adults (Letts et al. 2010; Stevens et al. 2001, Northridge et al. 1995; Berg et al. 1997). Obviously, 
spending more time in one place may result in a greater number of falls there. Hence, more falls would be expected to occur in the living room and the kitchen, the most commonly used areas. However, the highest number of falls occurred in the bedroom, although the bedroom is used mostly at night and is associated with few activities. The activities that being performed in the bedroom are demanding tasks. For instance, getting up in the night when people are drowsy, and sleepy or getting dressed/undressed which may lead to increase the risk of fall. The results also show that there has been at least one fall incident in all areas of an apartment in Hässelgården's senior housing - even in the balcony and the bathroom, despite the shorter amount of time spent there by the residents. This finding may underscore the importance of making physical adaptations to senior housing so as to meet the needs of older adult residents.

As expected, the older residents perceived the living room, with the highest score based on UD principles, as the safest area of their apartments, followed by bedrooms and kitchen. The physical features of the living room and the limited number of activities performed there contribute to this safety perception (Alcántara et al. 2005; Weber Corseuil et al. 2012). The kitchen and the living room are usually where functional objects, such as the stove, other appliances (kitchen), the TV, the sofa, and the computer (living room), needed for daily routine activities are located. Other objects, such as photographs, paintings, and knick-knacks (small decorative objects, especially in the house, shelves, etc.), are regarded as mementos and are found in the living room. Moreover, multiple activities are carried out in the kitchen and the living room. In the kitchen, many necessary activities such as cooking, eating, taking medication, and washing dishes are conducted in the course of a routine day. The living room is usually associated with activities related to relaxation, realization, and self-expression (e.g. listening to music, reading a book, and watching TV).

Overall, the results of this study indicate that a higher score based on UD principles for an area may predict the greater use of that area, lower number of falls, and higher perceived safety. A lower score based on UD principles for an area in this study may predict only a higher number of falls and not necessarily lower levels of safety perception and frequency of use. Therefore, our results highlight the effectiveness of the application of UD to the living environment of residents for its fall-related injury reduction but not for other dimensions of well-being considered in this study (use of space, safety perception). For instance, the participants in this study regarded the bathroom to be the least safe area of their apartments; however, in actuality, the bedroom had the lowest UD score and was the site of the highest number of falls. The participants' perception of the bathroom as the least safe area of their apartments could be related to the presence of environmental hazards and the lack of certain assistive products (Zamora et al. 2008), as well as other factors, such as performing relevant challenging activities. The bathroom is the area of an apartment that is associated with necessary routine activities for personal care and hygiene that could be perceived with some degree of concern by older adults. Moreover, the furniture and texture of the floor and walls of the bathroom may promote the residents' perceived lack of safety.

\section{Implications and looking ahead}

This study sets out to assess how the physical features of the indoor environment of older adults' houses may influence and be related to their use of space, experience of falls, and safety perception. Different areas of a senior housing apartment exhibit different potential risk factors for use of space, falls, and safety. Furthermore, some parts 
of the apartments show a clear difference between the quantity of use (time spent) and quality of use, that is what kind of activities are performed. For instance, bathrooms are characterized as low in frequency of use, but the activities that are performed there are challenging like undressing, showering, and sitting down. Elderly falls may be related to the apartment layout and the lack of required modifications (especially in the bathroom) to meet the needs of seniors. However, having a safe environment to live is not only related to proper design and layout. The ways in which the furniture is organized (apartments are often 'over-furnitured') and the apartment is decorated also play a role. Not surprisingly, older adults tend to hold on to their belongings because these objects represent their memories and identity or they might be economically valuable (Ekerdt et al. 2004). However, doing so creates problems for older adults living in senior housing (an apartment with a floor area of 52-57 $\mathrm{m}^{2}$ ).

Many participants suggested changing the windows because they are not easy to open. Moreover, the presence of thresholds in the floor in some areas, especially the balcony, makes walking difficult, and it is where one can trip and fall. Installing a proper ventilation system in the kitchen may also make it a more pleasant place for seniors to spend time there. Making a list of safety improvements for residents is not a simple task. Table 2 summarizes the problems that exist in different areas of Hässelgården's senior housing and presents several suggestions that may reduce seniors' falls, improve use of space, and elevate seniors' safety perception. Micasa, working together with renovation companies, can install a proper night light system (preferably amber/red light) in the walls, floors, and ceiling to help seniors navigate the space from the bedroom to the bathroom and the kitchen. Stockholm Municipality and Micasa can also encourage residents to use fitted carpet that covers a floor entirely (instead of mats) to prevent fall-related injuries. In addition, Micasa and renovation companies can work together to make various other improvements such as placing non-skid mat/strips on the shower floor and constructing a safety glass or plastic wall to separate the shower area from the bathroom. Moreover, porcelain toilets can be covered with soft damping material as a simple way in which to avoid the severity of the injury during a fall. Installing handrails and grab bars in some parts of the living room or bedroom will also make walking easier and less risky for residents.

As the study focused on the interplay between a person and his/her living environment, any remedy to mitigate this should be made with regard to this mutual interaction. The universal design is about the need of 'mutual' adaptation of both individuals and their environment. Acting on individuals (e.g. increasing their awareness about their living environment) may lead to their better adaption to the living environment. On the other hand, the individuals' living area shall be adapted through design approaches based on the needs of the users. However, these two strategies may be employed in synergistic to meet the goal.

Senior housing residents should be informed about the possible risk factors in their immediate environment so as to ensure their safe indoor mobility. Some of the residents' interview responses indicate that they lack adequate information about environmental risk factors-for instance, how easily a fall could happen. Holding informative meetings/ programmes about the potential risk factors associated with injuries may promote safety. These meetings could be held, e.g. seasonally by the municipality to inform and update the residents about safety issues. On the other hand, this could be a suitable platform to know more about the resident's problems and difficulties.

Another suggestion to reduce risk of fall and improve safety is the performance of regular inspections of apartments by social care, for instance, could potentially decrease the risk of tripping (e.g. electrical cords, rugs, paintings or other objects that can lead to injury) among older adult's residents. These visits may determine those triggers of falls 


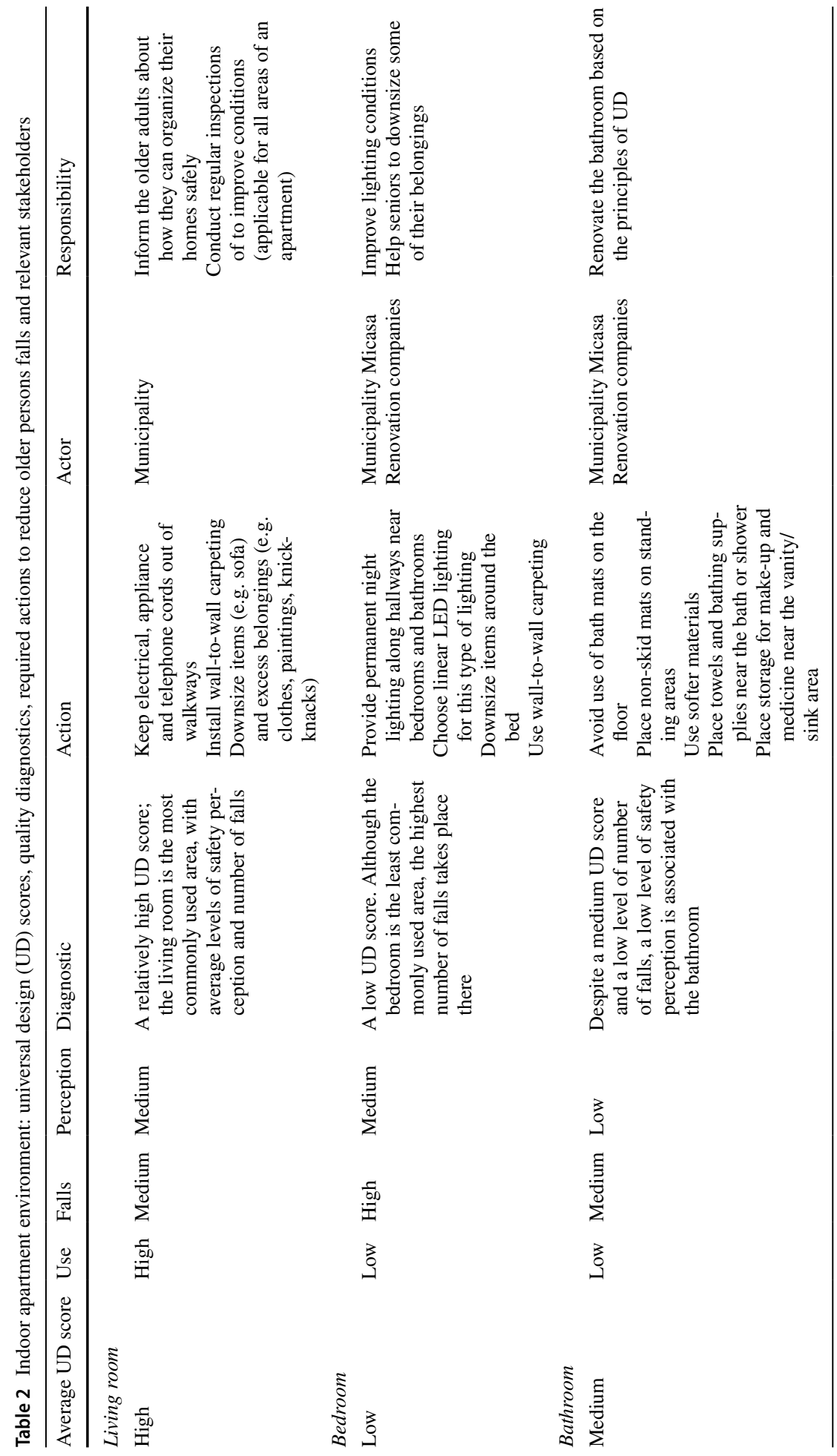




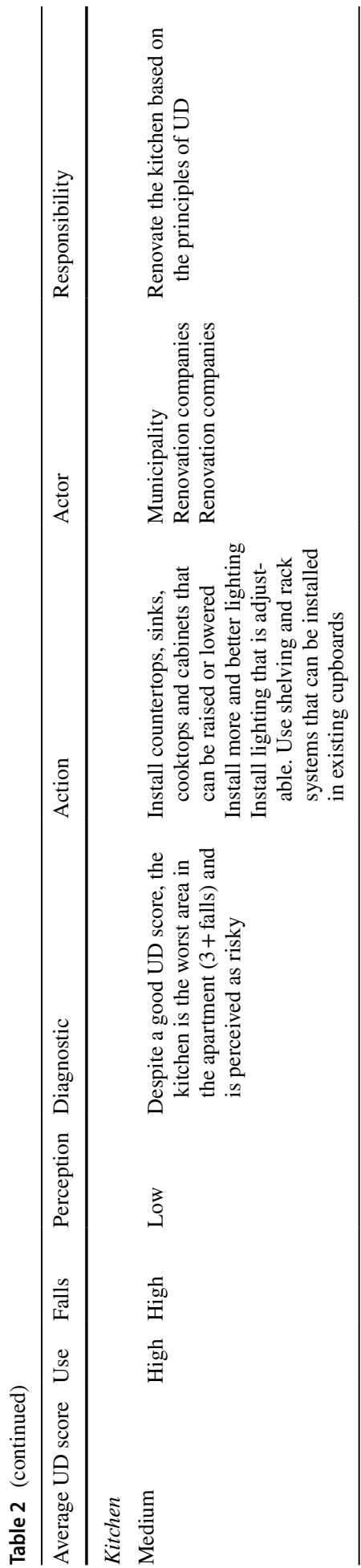

Springer 
related to the placement of the furniture and provide a guideline for the better use of space in the apartments.

However, of perhaps greater importance is providing residents with safety information, as well as the results of these inspections. (These inspection reports are usually produced for internal circulation among municipal officials and politicians.) The housing company could also be directly involved in helping residents to plan the placement of furniture when moving from a larger apartment to Hässelgården's senior housing.

If safety is an individual right, then the municipality of Stockholm is obliged to implement a systematic assessment of housing standards in all seniors' apartments. This process would benefit from an open discussion with housing companies and service providers (private sector). When this framework is in place, the next relevant issue is where to begin making modifications: bathrooms or kitchens? Certainly, the older persons who live in these apartments are the ones who know best where to start. Hence, they should be the first ones to be consulted regarding the prioritization of adaptations to these apartments.

Although many private companies in Sweden are involved in delivering services to seniors' houses, the municipalities are ultimately responsible for making sure that these services are delivered. The municipalities also need to supervise the quality of these services. At the regional level, the National Board of Health and Welfare has a web page (Äldreguiden) that allows older adults to compare the services delivered by different companies, thus providing them with the knowledge necessary to make informed decisions about which senior housing to choose that best meets their needs and priorities. The information on the web page is obtained from surveys answered by Swedish senior citizens. Municipalities may also use this information as a tool to assess the quality of each service company and to aid decisions regarding the extension of contracts.

Although these suggestions may be relevant to Hässelgården, they may be also relevant to other older adult's residential areas in Stockholm, and elsewhere. This study contributes knowledge of how senior citizens use their apartments and perceive their housing environment. More studies are needed to investigate whether current housing standards meet the needs of the older adults in Sweden. In addition, further studies could focus on how the available housings in the market may be upgraded according to the specific needs of the residents, and how older adults can be adapted to their living environment associated with environmental hazards without impeding their independence.

Acknowledgements I would like to thank the Lars Erik Lundberg Scholarship Foundation for funding this study. My thanks go to Vania Ceccato for her help in conducting this study. I would also like to acknowledge the support of Micasa the residents of Hässelgården for making this study possible.

Funding Funding was provided by lLars Erik Lundberg Scholarship Foundation (Grant No. 695971).

Open Access This article is distributed under the terms of the Creative Commons Attribution 4.0 International License (http://creativecommons.org/licenses/by/4.0/), which permits unrestricted use, distribution, and reproduction in any medium, provided you give appropriate credit to the original author(s) and the source, provide a link to the Creative Commons license, and indicate if changes were made. 


\section{Appendix 1: Checklist}

1. Inside and outside door handles and locks are easy to operate.

- Entrance $\quad$ Yes $\square \quad \mathrm{No} \square$

- Bathroom Yes $\square \quad \mathrm{No} \square$

- Living room Yes $\square \quad \mathrm{No} \square$

- Kitchen $\quad$ Yes $\square$ No $\square$

- Bedroom Yes $\square$ No $\square$

- Balcony Yes $\square$ No $\square$

- Closet Yes $\square$ No $\square$

2. Doors have lever-action handles instead of round knobs.

- Entrance $\quad$ Yes $\square \quad \mathrm{No} \square$

- Bathroom Yes $\square \quad \mathrm{No} \square$

- Living room Yes $\square \quad \mathrm{No} \square$

- Kitchen $\quad$ Yes $\square$ No $\square$

- Bedroom Yes $\square \quad \mathrm{No} \square$

- Balcony Yes $\square$ No $\square$

- Closet Yes $\square$ No $\square$

3. Door thresholds are low and bevelled, or there should be no thresholds.

- Entrance Yes, it is bevelled $\square$ No, it is not. $\square$

- Bathroom Yes, it is bevelled $\square$ No, it is not. $\square$

- Living room Yes, it is bevelled $\square$ No, it is not. $\square$

- Kitchen Yes, it is bevelled $\square$ No, it is not. $\square$

- Bedroom Yes, it is bevelled $\square$ No, it is not. $\square$

- Balcony Yes, it is bevelled $\square$ No, it is not. $\square$

- Closet Yes, it is bevelled $\square$ No, it is not. $\square$

There is no threshold. $\square$ There is no threshold. $\square$ There is no threshold. $\square$ There is no threshold. $\square$ There is no threshold. $\square$ There is no threshold. $\square$ There is no threshold. $\square$

4. Windows open easily from the inside, but they have a secure locking system that can prevent someone from entering from the outside.

- Living room Yes $\square \quad \mathrm{No} \square$

- Kitchen Yes $\square$ No $\square$

- Bedroom Yes $\square$ No $\square$

- Balcony Yes $\square$ No $\square$

5. Medications are stored in a safe place according to instructions on the label of the package or container.

Yes $\square \quad$ No $\square$

6. Carpeting and rugs are not worn or torn.

- Entrance $\quad$ Yes $\square$ No $\square$

- Bathroom Yes $\square \quad \mathrm{No} \square$

- Living room Yes $\square \quad \mathrm{No} \square$

- Kitchen $\quad$ Yes $\square$ No $\square$ 
- Bedroom $\quad$ Yes $\square$ No $\square$

- Balcony Yes $\square \quad \mathrm{No} \square$

- Closet Yes $\square$ No $\square$

7. Small, loose rugs have non-skid backing

- Entrance Yes $\square$ No $\square$

- Bathroom Yes $\square$ No $\square$

- Living room Yes $\square \quad \mathrm{No} \square$

- Kitchen Yes $\square$ No $\square$

- Bedroom Yes $\square$ No $\square$

- Balcony Yes $\square$ No $\square$

- Closet Yes $\square$ No $\square$

8. Small, loose rugs are not placed in traffic areas of the home.

- Entrance $\quad$ Yes $\square$ No $\square$

- Bathroom Yes $\square$ No $\square$

- Living room Yes $\square$ No $\square$

- Kitchen Yes $\square$ No $\square$

- Bedroom Yes $\square$ No $\square$

- Balcony Yes $\square$ No $\square$

- Closet Yes $\square$ No $\square$

9. Appliances, lamps, and cords are clean and in good condition.

- Entrance Yes $\square \quad$ No $\square$

- Bathroom Yes $\square$ No $\square$

- Living room Yes $\square \quad \mathrm{No} \square$

- Kitchen Yes $\square$ No $\square$

- Bedroom Yes $\square$ No $\square$

- Balcony Yes $\square$ No $\square$

- Closet Yes $\square$ No $\square$

10. There are enough lumps in each area.

- Entrance $\quad$ Yes $\square$ No $\square$

- Bathroom Yes $\square$ No $\square$

- Living room Yes $\square \quad \mathrm{No} \square$

- Kitchen Yes $\square$ No $\square$

- Bedroom Yes $\square$ No $\square$

- Balcony Yes $\square$ No $\square$

- Closet Yes $\square$ No $\square$

11. Outlets are located where they are needed in every room.

- Entrance $\quad$ Yes $\square \quad \mathrm{No} \square$

- Bathroom Yes $\square$ No $\square$

- Living room Yes $\square \quad \mathrm{No} \square$

- Kitchen Yes $\square$ No $\square$ 
- Bedroom Yes $\square \quad$ No $\square$

- Balcony Yes $\square$ No $\square$

- Closet Yes $\square$ No $\square$

12. Electrical cords are placed out of the flow of traffic and out from underneath rugs and furniture.

- Entrance $\quad$ Yes $\square \quad$ No $\square$

- Bathroom Yes $\square \quad$ No $\square$

- Living room Yes $\square \quad \mathrm{No} \square$

- Kitchen Yes $\square$ No $\square$

- Bedroom Yes $\square$ No $\square$

- Balcony Yes $\square$ No $\square$

- Closet Yes $\square$ No $\square$

13. Smoke alarms are present in the home and are in working order. Yes $\square \quad$ No $\square$

\section{Entrance and Halls}

\begin{tabular}{|l|l|l|l|}
\hline 14. Entrance is hazardous free. & Yes $\square$ & No $\square$ & \\
\hline 15. Hallways are equipped with night-lights. & Yes $\square$ & No $\square$ & \\
\hline 16. Room entrances do not have raised door thresholds. & Yes $\square$ & No $\square$ & \\
\hline 17. The closets door opens easily. & Yes $\square$ & No $\square$ & \\
\hline
\end{tabular}

\section{Living Room}

\begin{tabular}{|c|c|c|}
\hline $\begin{array}{l}\text { 18. Electrical cords are placed along walls (not under rugs) } \\
\text { and away from traffic areas. }\end{array}$ & Yes $\square$ & No $\square$ \\
\hline 19. Chairs and sofas are sturdy and secure. & Yes $\square$ & $\mathrm{No} \square$ \\
\hline $\begin{array}{l}\text { 20. Chairs and sofas are not too low or too deep to get in } \\
\text { and out of easily. }\end{array}$ & Yes $\square$ & No $\square$ \\
\hline $\begin{array}{l}\text { 21. Chairs and sofas have full arms to aid in sitting or } \\
\text { rising. }\end{array}$ & Yes $\square$ & No $\square$ \\
\hline 22. The light switch is located near the entrance. & Yes $\square$ & No $\square$ \\
\hline $\begin{array}{l}\text { 23. There is enough space to walk through the room leaving } \\
\text { clear passageways for traffic. }\end{array}$ & Yes $\square$ & No $\square$ \\
\hline $\begin{array}{l}\text { 24. Furniture, which might be used for support when } \\
\text { walking or rising, is steady and does not tilt. }\end{array}$ & Yes $\square$ & $\mathrm{No} \square$ \\
\hline
\end{tabular}




\section{Bathroom}

\begin{tabular}{|c|c|c|c|}
\hline $\begin{array}{l}\text { 25. The shower has a non-skid mat or strips on the standing } \\
\text { area. }\end{array}$ & Yes $\square$ & $\mathrm{No} \square$ & \\
\hline 26. Shower doors are safety glass or plastic. & Yes $\square$ & $\mathrm{No} \square$ & \\
\hline $\begin{array}{l}\text { 27. Grab bars are installed on the walls by the shower areas, and } \\
\text { toilets }\end{array}$ & Yes $\square$ & No $\square$ & \\
\hline $\begin{array}{l}\text { 28. The towel bars and the soap dish in the shower stall are } \\
\text { durable and are firmly installed. }\end{array}$ & Yes $\square$ & No $\square$ & \\
\hline 29. A single-lever mixing faucet is used. & Yes $\square$ & No $\square$ & \\
\hline 30. You have faucet handles that are easy to grasp. & Yes $\square$ & $\mathrm{No} \square$ & \\
\hline 31. Bathroom flooring is not shiny. & Yes $\square$ & $\mathrm{No} \square$ & \\
\hline $\begin{array}{l}\text { 32. Bathroom rugs are low pile commercial carpet (no throw } \\
\text { rugs or bathmats). }\end{array}$ & Yes $\square$ & No $\square$ & \\
\hline 33. Bathroom has even lighting without shine. & Yes $\square$ & No $\square$ & \\
\hline 34. The light switch is near the door. & Yes $\square$ & No $\square$ & \\
\hline 35. The bathroom door opens outward. & Yes $\square$ & $\mathrm{No} \square$ & \\
\hline $\begin{array}{l}\text { 36. The bathroom has a safe supplemental heat source and } \\
\text { ventilation system. }\end{array}$ & Yes $\square$ & No $\square$ & \\
\hline 37. The toilet material is soft to avoid injury. & Yes $\square$ & $\mathrm{No} \square$ & \\
\hline
\end{tabular}

\section{Bedroom}

\begin{tabular}{|l|l|l|l|}
\hline 38. A lamp or flashlight is kept within reach of your bed. & Yes $\square$ & No $\square$ & \\
\hline $\begin{array}{l}\text { 39. A night-light is used to brighten the way to the bathroom at } \\
\text { night. }\end{array}$ & Yes $\square$ & No $\square$ & \\
\hline 40. Plenty of room is left for you to walk around the bed. & Yes $\square$ & No $\square$ & \\
\hline $\begin{array}{l}\text { 41. You have an adequate-sized nightstand or small table for the } \\
\text { telephone, glasses, or other important items. }\end{array}$ & Yes $\square$ & No $\square$ & \\
\hline 42. There is a sturdy chair with arms where you can sit to dress. & Yes $\square$ & No $\square$ & \\
\hline 43. You have wall-to-wall low pile carpeting . & Yes $\square$ & No $\square$ & \\
\hline
\end{tabular}

\section{Kitchen}

44. The range and sink areas have adequate light levels.

Yes $\square \quad$ No $\square$ 


\begin{tabular}{|c|c|c|c|}
\hline $\begin{array}{l}\text { 45. If you have a gas range, it is equipped with pilot lights and } \\
\text { an automatic cut-off in the event of flame failure. }\end{array}$ & Yes $\square$ & $\mathrm{No} \square$ & \\
\hline $\begin{array}{l}\text { 46. If you have an exhaust hood for the oven, it has easily } \\
\text { removable filters for proper cleaning. }\end{array}$ & Yes $\square$ & $\mathrm{No} \square$ & \\
\hline $\begin{array}{l}\text { 47. The kitchen exhaust system is internally vented, discharges } \\
\text { directly outside, or discharges through ducts to the outside } \\
\text { and not into the other unused space. }\end{array}$ & Yes $\square$ & $\mathrm{No} \square$ & \\
\hline $\begin{array}{l}\text { 48. Countertop space lets you keep carrying and lifting to a } \\
\text { minimum. }\end{array}$ & Yes $\square$ & No $\square$ & \\
\hline 49. Kitchen wall cabinets are not too high to be easily reached. & Yes $\square$ & No $\square$ & \\
\hline 50. Lighting of counter tops is enough for meal preparation. & Yes $\square$ & $\mathrm{No} \square$ & \\
\hline 51. Light switches are located near the doors. & Yes $\square$ & No $\square$ & \\
\hline 52. Shiny work surfaces are not used in countertops. & Yes $\square$ & $\mathrm{No} \square$ & \\
\hline 53. Oven controls are clearly marked and easily grasped. & Yes $\square$ & No $\square$ & \\
\hline $\begin{array}{l}\text { 54. A single-lever mixing faucet is used. This type of faucet } \\
\text { controls both the hot and cold water flow with a single } \\
\text { control. }\end{array}$ & Yes $\square$ & No $\square$ & \\
\hline 55. Flooring is not slippery and has a non-glare surface. & Yes $\square$ & $\mathrm{No} \square$ & \\
\hline 56. Small appliances are unplugged when not in use. & Yes $\square$ & No $\square$ & \\
\hline 57. Knives are kept in a knife rack or drawer. & Yes $\square$ & $\mathrm{No} \square$ & \\
\hline $\begin{array}{l}\text { 58. Countertops and work areas are cleared of all unnecessary } \\
\text { objects. }\end{array}$ & Yes $\square$ & $\mathrm{No} \square$ & \\
\hline 59. Drawers and cupboards are kept closed. & Yes $\square$ & $\mathrm{No} \square$ & \\
\hline $\begin{array}{l}\text { 60. A sturdy, stable stepladder or step stool is used rather than a } \\
\text { chair to reach objects in overhead cabinets. }\end{array}$ & Yes $\square$ & $\mathrm{No} \square$ & \\
\hline 61. Grease or liquid spills are wiped up at once. & Yes $\square$ & No $\square$ & \\
\hline
\end{tabular}

\section{More comments}




\section{Appendix 2: Survey}

\section{Questions about you}

1. Age:

2. Sex:

$\square$ Male $\square$ Female

3. Birth place: Country:

4. Previous occupation:

5. Marital Status
Married or cohabiting
$\square$ living apart
$\square$ Single
$\square$ Other

6. How long have you lived in your present home?

$\square$ Less than a year $\square$ 1-5 years $\square$ More than 5 years

7. How do you assess your personal health?

$\square$ Overall good

$\square$ Good but I have a lot less trouble

$\square$ Good but I have some major problems (such as not being able to be out särksilt long).

$\square$ Not very well (for example, can not leave my apartment very often).

$\square \mathrm{Bad}$

8. Are you taking any medication?

$\square$ Yes, every day.

$\square$ three times per week.

$\square$ twice per week.

$\square$ Once a week.

$\square$ Never.

9. Does medicine affect your mobility?

$\square$ Yes $\quad \square$ No

10. Tobacco - Do you smoke?

$\square$ Yes, often $\quad \square$ Sometimes $\quad \square$ Rarely $\quad \square$ No, never. 
11. Do you drink alcohol?

$\square$ Yes, often several times a week.

$\square$ several monthly.

$\square$ Rarely

$\square$ No, never.

12. Select the following options regarding vision and hearing:

$\square$ I need glasses for most things I do.

$\square$ I need hearing aids to hear.

$\square$ I do not need glasses for most things I do.

$\square$ I do not need hearing aids to hear.

13. Do you frequently have pains in the joints, when you go?

$\square$ Yes $\cdot$ No

14. Which sentence best describes you?

$\square$ I almost never go out.

$\square$ I go out at least a few times per week.

$\square$ I go out at least once per day.

$\square$ I go out several time per day.

15. What types of walking aids do you need to move around inside your apartments?

$\square$ I need a cane to walk.

$\square$ I GARAM need to go.

$\square$ I need a walker to walk.

$\square$ I need a wheelchair.

$\square$ I have eloped.

$\square$ can walk unaided.

16. Do you fear that when you take a shower?

$\square$ Always $\square$ Frequently $\square$ Sometimes $\square$ Rarely $\square$ Never

17. Have you ever been with a crime of any kind in your home or in places in its vicinity in Hässelgården?

$\square$ Yes $\cdot$ No If no, go to question 19 !

18. Which type of crime, you have been victim of in Hässelgården?

$\square$ theft, burglary

$\square$ Physical abuse, threats, robbery

$\square$ Fraud

Other

\section{Questions about your apartment}

19. Suppose this is your apartment plan. Where do you spend the most time in your apartment? Write down on map 1 "where you spend the most time. 2" the other place you spend most of your time and " 3 " on the third place you spend most of your time. See the example below::

EXEMPEL

Now this is your turn! 

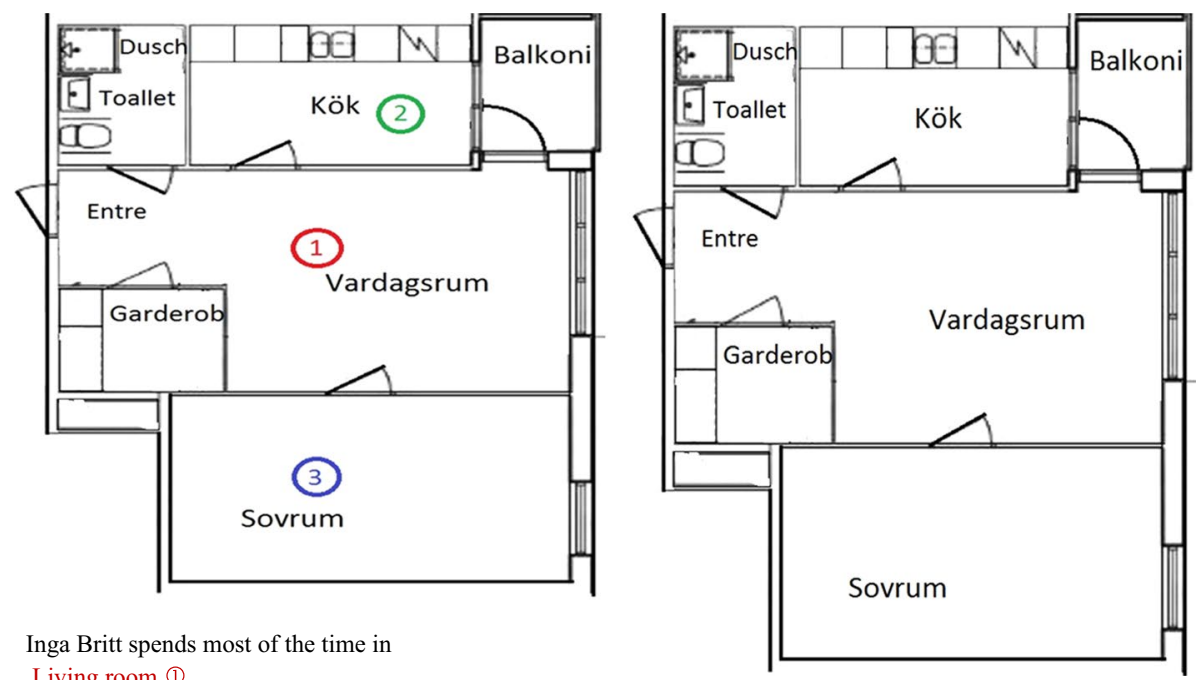

Inga Britt spends most of the time in

Living room (1)

Followed by kitchen (2)

And then in bedroom(3)

Your apartment may not have any closet.

20. Where have you fallen in your apartment? Tick in the places where you have fallen. See the example below first. (If you've never fallen go to question 23!)

EXEMPEL

Now this is your turn! 

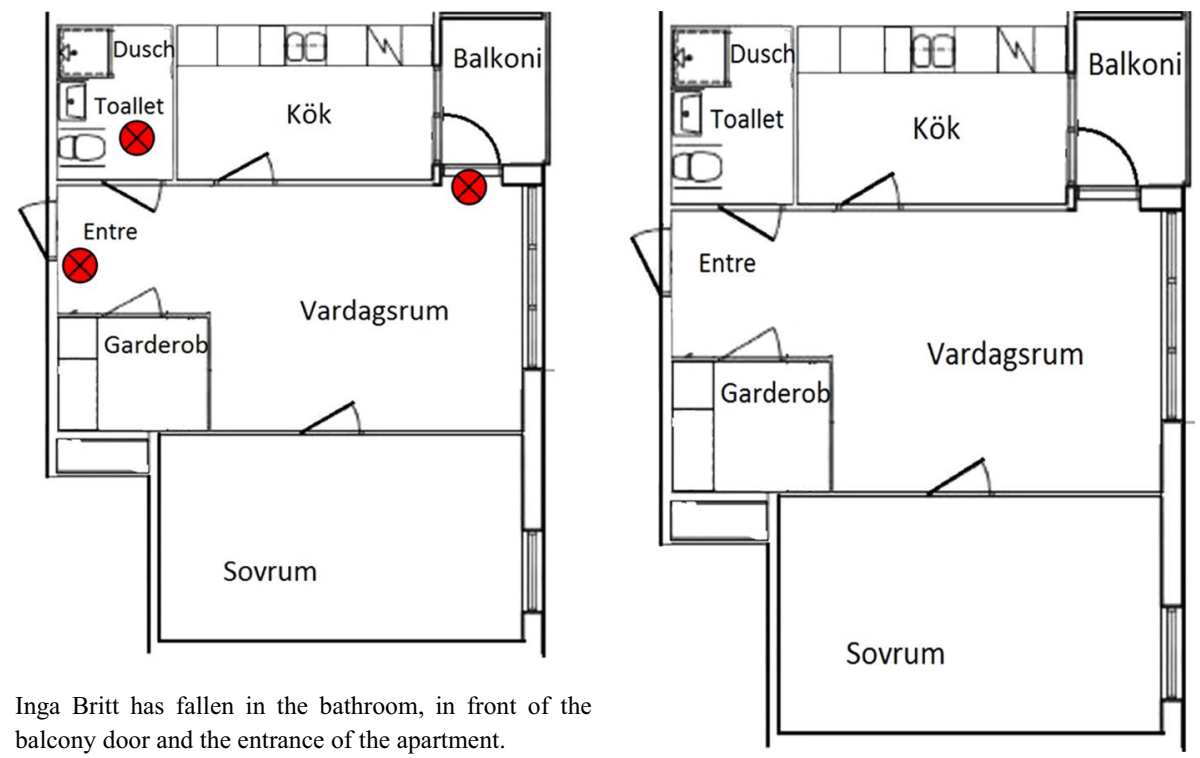

Inga Britt has fallen in the bathroom, in front of the balcony door and the entrance of the apartment.

21. Have you ever fallen in your apartment?

$\square$ Every day.

$\square$ Several times a week.

$\square$ only a few times.

22. Briefly describe the situation when the worst fall in your apartment. For example, Inga Britt describes her fall in the balcony as the following: "I fell on the eve of balkogen when I would go there one morning. I did not notice eve at that moment, and I broke my wrist." 
23. How often do you stumble on the stairs?

$\square$ Often

$\square$ Quite often

$\square$ Sometimes

$\square$ Rarely

$\square$ Never

24. Mark on the map the parts of your apartment that you feel safest in? Please write 1 "the safest place, 2 " where it is partially secure, and 3 "where it feels totally insecure." See the example first.

EXEMPEL

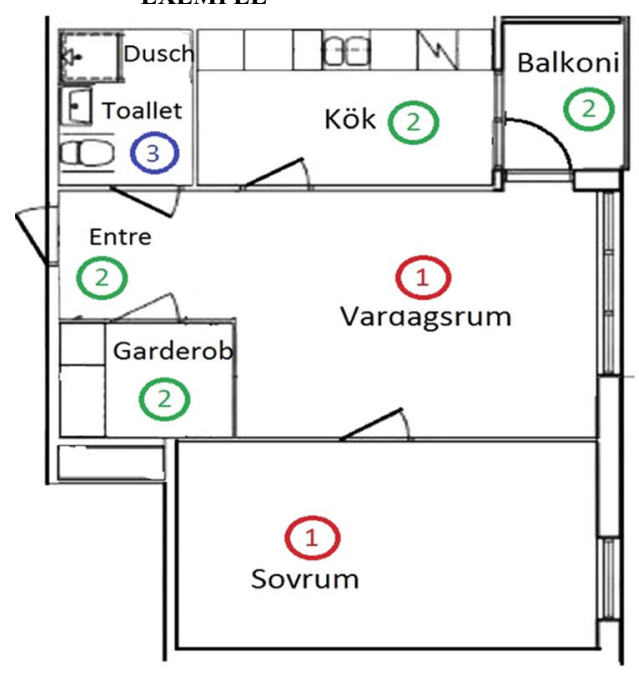

Inga Britt feels safest when she is in living room and bedroom (1), She feels partially insecure in entrance, closet, balcony, and kitchen, toilet and shower areas are the most unsafe places for her (3).
Now this is your turn!

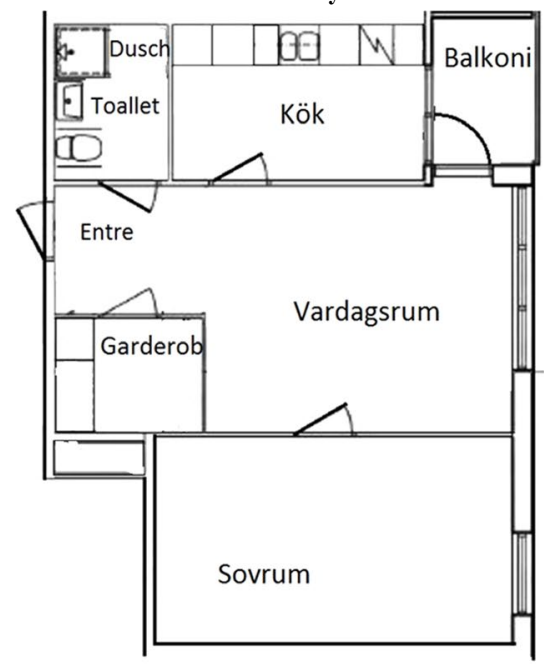

25. Are you satisfied with the property manager's services to you and your home (my needs are handled efficiency, quality of repairs are satisfactory)?

$\square$ Yes $\quad \square$ No 
26. How do you think that your apartment may be safer and better for you?

$\square$ The thresholds must be low and flattened, or so they should be removed.

$\square$ The doors should open easily.

$\square$ The windows should be easy to open.

$\square$ Kitchen wall cabinets should be easy to reach.

$\square$ Toilet and sink should be made of softer material to fall injuries.

$\square$ Bathroom Floors must be made of materials that do not slip on.

$\square$ Ample space must be provided for us to be able to walk around the bed.

$\square$ Doors and hallways must be large enough so that there is plenty of room to pass through them.

If you have any more suggestions on how your apartment can be made safer, please write it down here!

\section{Questions about your home area}

27.Below is a map of Hasselgarrden Can you highlight to show the places you normally pass a typical day? If you cannot go out, please go to question 33 ! 

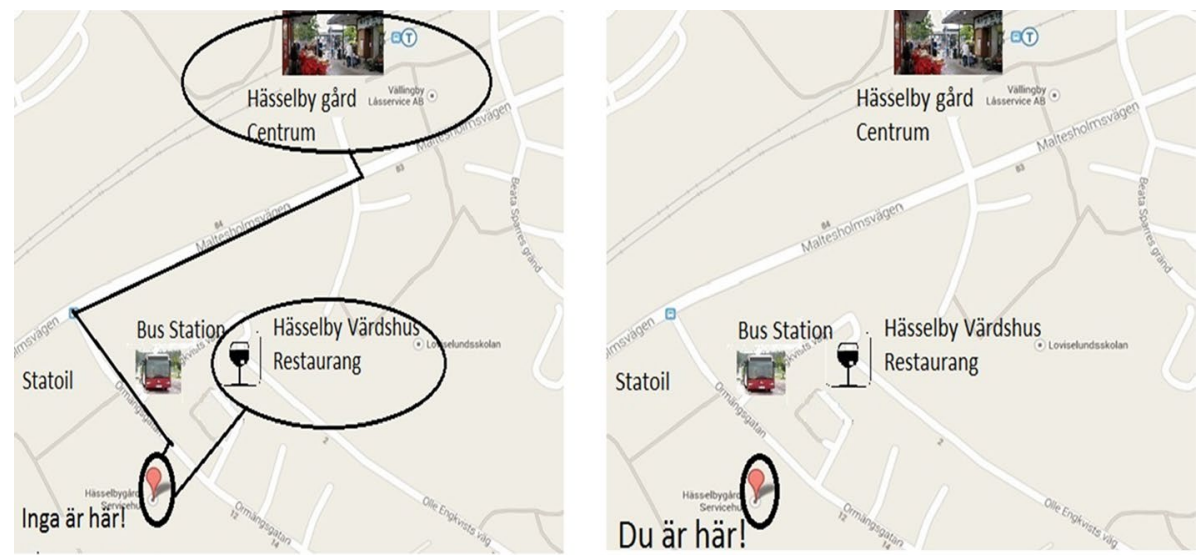

Inga Britt aves Hässelgården with walker and goes three times a week until Hässelby gård center. In the afternoon, she usually goes toHässelby Värdshus Restaurant with Olle.

28. Do you move around outdoors Hässelbygården?

$\square$ Yes, mostly on weekdays. • Yes, mostly on weekends. $・$ No

29. How often do you go out in the summer?

$\square$ Every day.
$\square$ few days a week.
$\square$ I rarely go out.
$\square$ I never go out.

30. How often do you go out in the winter?

$\square$ Every day.

$\square$ few days a week.

$\square$ I rarely go out.

$\square$ I never go out.

31. At what time do you usually go for walks during the summer in Hässelgården? $\square$ On the morning from 9:00 until 11:00.

$\square$ After lunch, 12: 00-16: $00 \mathrm{hrs}$.

$\square$ Em 16: 00-21: 00 hrs.

32. At what time do you usually go for walks during the winter in Hässelgården? $\square$ On the morning from 9:00 until 11:00.

$\square$ After lunch, 12: 00-16: $00 \mathrm{hrs}$.

$\square$ Em 16: 00-21: $00 \mathrm{hrs}$. 
33. Have you ever fallen around Hässelgården? If you have never fallen out of your immediate surroundings, go to question 38 !

$\square$ Every day.

$\square$ Several times a week.

$\square$ Only a few times.

34. Where have you fallen most in your area?

$\square$ In Hässelgårdens garden.

$\square$ Near the entrance to the farm Hässelby senior housing.

$\square$ Near petrol station Statoil.

$\square$ In the field Hasselbygårds center.

$\square$ Near Ormänstorget.

$\square$ Near the bus station.

$\square$ In laundry

35. What is the place like where you fell in Hässelgården ? Can you tell us in detail how Happened?

36. When you have the most fallen outdoors in your local environment in Hässelgården ??

$\square$ Winter

$\square$ Spring

$\square$ Summer

$\square$ Fall

37. Was it dark?

$\square$ Yes $\square$ No 
38. in which parts of your outdoor environment you feel safest in Hässelgården? Mark with a cross

$$
\text { Mostly safe } \quad \begin{gathered}
\text { Partially } \\
\text { unsafe }
\end{gathered} \text { Totally unsafe }
$$

In Hässelgårdens garden.

Near the entrance to the

Hässelgårdens senior housing.

Near the petrol station Statoil.

In the area Hasselbygårds

center.

Near Ormänstorget.

Near the bus station.

In the laundry

39. Do you think the walkways and paths wandering in your immediate environment feel slip resistant and safe to walk on in Hässelgården?

$\square$ In the summer, they are good, but they feel unsafe in the winter.

$\square$ Yes, they feel secure in both summer and winter.

$\square$ No, they do not feel at all safe.

$\square$ Do not know, I'm rarely there.

40. Are you worried about becoming a victim of a crime of any kind in your home or in places in its vicinity in Hässelgården?

$\square$ Yes, for theft, burglary.

$\square$ Yes, to beatings, threats, robbery.

$\square$ Yes, for fraud.

$\square$ No, I do not feel worried.

41. What do you think about the following statements regarding the Hässelgården?

I like talking to neighbours who live in my

Fully agree Partially agree Not agree 
neighbourhood.

There are people in my neighbourhood who I exchange small services.

Those who live in my neighbourhood are helpful to each other.

You can count on those who live in my neighbourhood.

There are some people in my neighbourhood that I can experience as threatening.

There are some people in my neighbourhood that I can experience as uninspiring.

42. How do you think your outdoor environment in Hässelgården can be made safer and better for you?

$\square$ Better lighting at doorways.

$\square$ Better lighting at trapper.

$\square$ Better lighting on porches.

$\square$ Better lighting at walkways.

$\square$ The snow must be plowed more often.

$\square$ Gator Alley and sidewalks must be sent more frequently during winter.

$\square$ Lower stairs to anyone with reduced mobility.

$\square$ Several streets suited to walkers and wheelchairs and others with mobility decreased.

$\square$ Place several signs at eye level, for those who use wheelchairs.

$\square$ Using non-slip paving.

$\square$ Provide frequent seat, even when it's cold out.

$\square$ staff around who can help if something happens.

If you have any more suggestions on how your outdoor area can be made safer write please, download here: 
43. How do you think your outdoor environment generally (in Stockholm) can be made safer and better for you?

Thanks for your participation!

\section{References}

Abramsson, M., \& Andersson, E. (2016). Changing preferences with ageing-housing choices and housing plans of older people. Housing, Theory and Society, 33(2), 217-241. 
Abramsson, M., Elmqvist, A., \& Magnusson Turner, L. (2014). Elder's relocations and motives for moving or staying: Writing in the government mission stay well at elderly, help center. Linköping: National Institute for Aging and Aging Research (NISAL).

Abramsson, M., \& Niedomysl, T. (2008). Elderly persons relocations and housing preferences. Stockholm: Institute for Future Studies.

Agahi, N., \& Parker, M. (2005). Are today's older people more active than their predecessor? Participation in leisure-time activities in Sweden in 1992 and 2002. Ageing \& Society, 25(6), 925-941.

Alcántara, E., Artacho, M. A., González, J. C., \& García, A. C. (2005). Application of product semantics to footwear design. Part I-identification of footwear semantic space applying diferential semantics. International Journal of Industrial Ergonomics, 35(8), 713-725.

Andersson, E. K., \& Abramsson, M. (2012). Residential mobility patterns of elderly-leaving the house for an apartment. Housing Studies, 27(5), 582-604.

Ayis, S., Gooberman-Hill, R., Ebrahim, S., \& MRC Health Services Research Collaboration. (2003). Longstanding and limiting long-standing illness in older people: Associations with chronic diseases, psychosocial and environmental factors. Age and Ageing, 32(3), 265-272.

Baldrica, N. (2003). The accessible home: Updating your home for changing physical needs. Chanhassen: Creative Publishing International.

Bamzar, R., \& Ceccato, V. (2015). The nature and the geography of elderly injuries in Sweden. GeoJournal, 80(2), 279-299.

Bamzar, R., \& Ceccato, V. (2016). The regional ecology of elderly falls in Sweden. GeoJournal, 81(1), 23-36.

Befring, Edvard. (1994). Research methodology and statistics. Lund: Studentlitteratur.

Berg, W. P., Alessio, H. M., Mills, E. M., \& Tong, C. (1997). Circumstances and consequences of falls in independent community-dwelling older adults. Age and Ageing, 26(4), 261-268.

Borson, S. (2010). Cognition, aging, and disabilities: Conceptual issues. Physical Medicine and Rehabilitation Clinics, 21(2), 375-382.

Bricki, N., \& Green, J. (2007). A guide to using qualitative research methodology. Retrieved May 15, 2015 from http://www.alnap.org/resource/13024.

Carr, K., Weir, P. L., Azar, D., \& Azar, N. R. (2013). Universal design: A step toward successful aging. Retrieved April 25, 2015 from https:/www.hindawi.com/journals/jar/2013/324624/.

Carter, S. E., Campbell, E. M., Sanson-Fisher, R. W., \& Gillespie, W. J. (2000). Accidents in older people living at home: A community-based study assessing prevalence, type, location and injuries. Australian and New Zealand Journal of Public Health, 24(6), 633-636.

Ceccato, V. (2016). Patterns of traffic accidents among elderly pedestrians in Sweden. Report submitted to Vägverkets Jubileumsfond, Stockholm.

Centre for Disease Control and Prevention. (2005). A home fall prevention checklist for older adults. Atlanta. Retrieved March 12, 2014 from https://www.cdc.gov/HomeandRecreationalSafety/pubs/Engli sh/booklet_Eng_desktop-a.pdf.

Commission for Architecture and the Built Environment (2008). Inclusion by design: Equality, diversity and the built environment. London: Seacourt. Retrieved March 3, 2014 from https://www.designcouncil. org.uk/sites/default/files/asset/document/inclusion-by-design.pdf.

Connell, B. R., Wolf, S. L., \& Atlanta FICSIT Group. (1997). Environmental and behavioral circumstances associated with falls at home among healthy elderly individuals. Archives of Physical Medicine and Rehabilitation, 78(2), 179-186.

Creswell, J. W. (2013). Research design: Qualitative, quantitative, and mixed methods approaches. London: Sage publications.

Crews, D. E., \& Zavotka, S. (2006). Aging, disability, and frailty: Implications for universal design. Journal of Physiological Anthropology, 25(1), 113-118.

Dahlin-Ivanoff, S., Haak, M., Fänge, A., \& Iwarsson, S. (2007). The multiple meaning of home as experienced by very old Swedish people. Scandinavian Journal of Occupational Therapy, 14(1), 25-32.

Davey, J. A., de Joux, V., Nana, G., \& Arcus, M. (2004). Accommodation options for older people in Aotearoa/New Zealand. Retrieved February 18, 2014 from https://www.beehive.govt.nz/sites/all/files /Accomodation\%20Options\%20for\%20Older\%20People.pdf.

Deardorff, C. J., \& Birdsong, C. (2003). Universal design: Clarifying a common vocabulary. Housing and Society, 30(2), 119-138.

Demirbilek, O., \& Demirkan, H. (2004). Universal product design involving elderly users: A participatory design model. Applied Ergonomics, 35(4), 361-370.

Ekerdt, D. J., Sergeant, J. F., Dingel, M., \& Bowen, M. E. (2004). Household disbandment in later life. The Journals of Gerontology Series B: Psychological Sciences and Social Sciences, 59(5), S265-S273. 
Fänge, A., \& Iwarsson, S. (2005). Changes in ADL dependence and aspects of usability following housing adaptation-a longitudinal perspective. American Journal of Occupational Therapy, 59(3), 296-304.

Fielo, S. B., \& Warren, S. A. (2001). Home adaptation: Helping older people age in place. Geriatric Nursing, 22(5), 239-246.

Forlizzi, J., DiSalvo, C., \& Gemperle, F. (2004). Assistive robotics and an ecology of elders living independently in their homes. Human-Computer Interaction, 19(1), 25-59.

Fuller, G. F. (2000). Falls in the elderly. American Family Physician, 61(7), 2159-2168.

Gill, T. M., Williams, C. S., Robison, J. T., \& Tinetti, M. E. (1999). A population-based study of environmental hazards in the homes of older persons. American Journal of Public Health, 89(4), 553-556.

Home Modification. (2008). Retrieved March 5, 2014 from http://gero.usc.edu/nrcshhm/resources/fs_home_ mod.pdf.

Ishihara, S., Ishihara, K., Nagamachi, M., \& Matsubara, Y. (1997). An analysis of Kansei structure on shoes using self-organizing neural networks. International Journal of Industrial Ergonomics, 19(2), 93-104.

Iwarsson, S., \& Ståhl, A. (2003). Accessibility, usability and universal design-positioning and definition of concepts describing person-environment relationships. Disability and Rehabilitation, 25(2), 57-66.

Iwarsson, S., Wahl, H. W., Nygren, C., Oswald, F., Sixsmith, A., Sixsmith, J., et al. (2007). Importance of the home environment for healthy aging: Conceptual and methodological background of the European ENABLE-AGE Project. The Gerontologist, 47(1), 78-84.

Leonardi, C., Mennecozzi, C., Not, E., Pianesi, F., Zancanaro, M., Gennai, F., \& Cristoforetti, A. (2009). Knocking on elders' door: Investigating the functional and emotional geography of their domestic space. In Proceedings of the SIGCHI conference on human factors in computing systems (pp. 17031712). ACM.

Letts, L., Moreland, J., Richardson, J., Coman, L., Edwards, M., Ginis, K. M., et al. (2010). The physical environment as a fall risk factor in older adults: Systematic review and meta-analysis of cross-sectional and cohort studies. Australian Occupational Therapy Journal, 57(1), 51-64.

Mace, R. L., Hardie, G. J., \& Place, J. P. (1991). Accessible environments: Toward universal design. In J. Lang, W. F. Preiser, J. C. Vischer, \& E. T. White (Eds.), Design interventions: Toward a more humane architecture. New York: Routledge.

Mace, R. L., Hardie, G. J., \& Place, J. P. (1996). Accessible environments: Toward universal design. Raleigh: The Center for Universal Design.

Montefusco, M. (2016). A Nordic region for all. Stockholm: Nordic Centre for Welfare.

Newell, A. F., \& Gregor, P. (2000). "User sensitive inclusive design"-in search of a new paradigm. In Proceedings on the 2000 conference on Universal Usability (pp. 39-44). ACM.

Nilson, F. (2014). Fall-related injuries amongst elderly in Sweden: Still an emerging risk? Thesis Dissertation, Karlstad University.

Northridge, M. E., Nevitt, M. C., Kelsey, J. L., \& Link, B. (1995). Home hazards and falls in the elderly: The role of health and functional status. American Journal of Public Health, 85(4), 509-515.

Orimo, H., Ito, H., Suzuki, T., Araki, A., Hosoi, T., \& Sawabe, M. (2006). Reviewing the definition of "elderly". Geriatrics \& Gerontology International, 6(3), 149-158.

Persson, H., Åhman, H., Yngling, A. A., \& Gulliksen, J. (2015). Universal design, inclusive design, accessible design, design for all: Different concepts-one goal? On the concept of accessibility-historical, methodological and philosophical aspects. Universal Access in the Information Society, 14(4), 505-526.

Pirie, G. H. (1979). Measuring accessibility: A review and proposal. Environment and Planning A, 11(3), 299-312.

Preiser, W. F., \& Ostroff, E. (2001). Universal design handbook. New York: McGraw Hill Professional.

Reinsch, S., MacRae, P., Lachenbruch, P. A., \& Tobis, J. S. (1993). Why do healthy older adults fall? Behavioral and environmental risks. Physical \& Occupational Therapy in Geriatrics, 11(1), 1-15.

Sandler, L., (2016). Universal design and green home survey checklist. University of Iowa Clinical Law Programs. Retrieved April 25, 2014 from https://law.uiowa.edu/sites/law.uiowa.edu/files/wysiwyg_uploa ds/UofIowaUDGreenHomeChecklistEnglishApril2016.pdf.

Sandstedt, E., \& Abramsson, M. (2012). Ny bostadspolitik för att möta en åldrande befolkning [New Housing Policies to Cater for an Ageing Population]. In M. Abramsson \& C. Nord (Eds.), Äldres boendeforskningsperspektive I Norden [Older People's Housing-Research Perspective in the Nordic Countries] (pp. 19-33). Lund: Studentlitteratur.

SCB, Statistics Sweden. (2015). Retrieved March 18, 2018 from http://statistik.stockholm.se/images/stori es/a-tabeller/a32.htm.

Stevens, M., Holman, C. A. J., \& Bennett, N. (2001). Preventing falls in older people: Impact of an intervention to reduce environmental hazards in the home. Journal of the American Geriatrics Society, 49(11), 1442-1447. 
Teddlie, C., \& Tashakkori, A. (Eds.). (2009). Foundations of mixed methods research: Integrating quantitative and qualitative approaches in the social and behavioural sciences. Thousand Oaks: Sage.

Van Hoof, J., Kort, H. S. M., Van Waarde, H., \& Blom, M. M. (2010). Environmental interventions and the design of homes for older adults with dementia: An overview. American Journal of Alzheimer's Disease \& Other Dementias, 25(3), 202-232.

Wahl, H. W., \& Oswald, F. (2010). Environmental perspectives on ageing. In D. Dannefer \& C. Phillipson (Eds.), The handbook of social gerontology (pp. 111-124). London: Sage Publication.

Weber Corseuil, M., Hallal, P. C., Xavier Corseuil, H., Jayce Ceola Schneider, I., \& d'Orsi, E. (2012). Safety from crime and physical activity among older adults: A population-based study in Brazil. Retrieved April 22, 2014 from https://www.hindawi.com/journals/jeph/2012/641010/.

World Health Organization. (2016). Retrieved June 17, 2017 from http://www.who.int/mediacentre/facts heets/fs344/en/.

Yiannakoulias, N., Rowe, B. H., Svenson, L. W., Schopflocher, D. P., Kelly, K., \& Voaklander, D. C. (2003). Zones of prevention: The geography of fall injuries in the elderly. Social Science and Medicine, 57(11), 2065-2073.

Zamora, T., Alcántara, E., Artacho, M. Á., \& Cloquell, V. (2008). Influence of pavement design parameters in safety perception in the elderly. International Journal of Industrial Ergonomics, 38(11), 992-998. 